\title{
Digital Marketing Strategy of Indonesian Agricultural Products
}

\author{
Juri Juswadi*, Pandu Sumarna, Neneng Sri Mulyati \\ Faculty of Agriculture \\ Universitas Wiralodra \\ Indramayu, Indonesia \\ *yuswadi_yuri@yahoo.co.id
}

\begin{abstract}
This research aims to determine the strategy for digital marketing of Indonesian agricultural products. The research method is SWOT (Strengths, Weaknesses, Opportunities, and Threats) analysis by using secondary data from the Central Bureau of Statistics (BPS), the ministry reports and various research results to establish the Internal and External Factor Analysis Summary (IFAS) and (EFAS) on aspects of agricultural products, digital infrastructure marketing and human resources. The result shows a) Strengths: product growth, product variety, product exports, product affordable price and agro-industrial raw material; b) Weaknesses: long marketing chain, small number of millennial farmers, baby boomers and veterans as majority farmers, low e-commerce penetration, bulky and perishable products, not yet good of logistics services and low farmers wages; c) Opportunities: ecommerce road map, millennial demography bonus, many cell phone users, sufficient number of internet users, growth income per capita, many culinary business, high e-commerce transaction and the increase in demand for raw materials of agro-industrial; d) Threats: low average development index of information and technology, little agricultural product start-ups, small valuation of agricultural product start-ups, needs of foreign funding for ecommerce and start up development, very little unicorn startups, weak internet infrastructure and increasing report number of e-commerce issues. According to IFAS and EFAS, the strategy is the Weaknesses-Opportunities strategy.
\end{abstract}

Keywords: agricultural products, startups, digital marketing, millennial

\section{INTRODUCTION}

The Indonesian agricultural product marketing is running through a long marketing chain most of the time due to some marketing agent looking for benefits which causing in the decrease of farmer income. The industrial era 4.0 gives big chance of increases of farmer income through the development of digital marketing that shortened marketing chain for agricultural product.

The strength of Indonesian agricultural products is the number and variety of food crops, plantations, livestock, fisheries and forestry for domestic and export needs. Many Indonesian products are included in the rising star category in the ASEAN market. There are nine agricultural products included in the rising star category in Thailand, namely fishery; cereals; sugars; meat, fish, and food preparation nest; vegetables saps and extract; dairy products and edible animal products; edible fruit; tress and flower [1].

The nature of perishable agricultural products and their large volume requires excellent and timely transportation in marketing. Product damage due to shipping weakness will injuries consumers. Digital marketing must be able to anticipate the distribution of agricultural products.

There are great opportunities and challenges in developing digital marketing of agricultural products due to external conditions that continue to change through the development of the industrial era 4.0. This opportunity should be taken for agricultural product marketing, however, the digital marketing only can run through the internet using cell phones and computers. Unfortunately, this device is only familiar to the millennial, and meanwhile internet user still low. Most of Indonesian farmer are generation $\mathrm{X}$ and baby boomers. There are only $16.04 \%$ millennial workers in the Indonesian agricultural sector. In 2017, the percentage of computer user is $19.11 \%$, while the internet user is $32.24 \%$ and cell phone user is $59.59 \%$ [2]. The development of Indonesian digital marketing is being supported by the e-commerce road map that has been published by the Indonesia government since 2017. The e-commerce road map has an important role in the change of agricultural products digital marketing.

The fundamental basis for the development of Digital Marketing in the business environment is the Internet. This is the technology that permits the use of electronic marketing techniques and has allowed the creation of the World Wide Web, as we know it today. It is the technology that has allowed the evolution and adaptation of traditional marketing techniques for the new digital environment [3]. There is a huge need of digital marketing infrastructure. Digital marketing infrastructure should include at least: the belt and road portal, companies-participants' web sites, online stores, social media accounts and social media marketing (SMM) activities, search engine optimization (SEO) activities, media and context advertisement, email marketing, Integrated customer relationship management (CRM) and e-CRM systems [4].

Internet has become a most effective means for promoting and enhancing purchasing via the promotion of products and the provision of any possible information existing, before selling. Also it contributes in facilitating the customers when 
buying and ordering, it helps financial transactions, secures delivering of products and preserves the prestige of the company while keeping clients satisfied after sales service [5].

The importance of farmer to understanding the internet can be seen from the results of the study that a farmer who wishes to sell his harvest through limakilo would have to sign up to the farmer webpage or contact the company via phone. What will happen next is the confirmation of the transaction via phone call. After the transaction is confirmed, the product will be published at the homepage of limakilo.id [6].

The importance of digital marketing is stated by the results of the study that a developing country can be rationalized and mechanized if it introduces e commerce effectively and efficiently. It will enhance its output and gives competitive advantage. Information technology (IT) has boosted e commerce worldwide. Now it's easier to enter to a new market and one can evaluate his/her product and company's performance. It reduces business overhead and enhances business management [7]. Digital marketing represents a huge opportunity for farmers in the future. The things which have to change are limited access to the market information, the literacy level among the farmers (in this point is very low) and multiple channels of distribution of both farmers and consumers [8].

Seeing this reality, the right strategy is needed in developing digital marketing of Indonesian agricultural products, in order to provide marketing efficiency which leads to an increase in farmers' income. The strategy for developing digital marketing of agricultural products is certainly based on existing internal and external factors. IFAS and EFAS analysis is a good effort in developing accurate strategies. The strategy development is important in facing the upcoming phenomena of the external environment on the Indonesian agricultural sector which consists of small-scale farming and farming enterprise. Digital marketing in this era is important as it is an opportunity that can be useful to achieve more efficient agricultural product distribution, wider market, and bigger chance for the farmers to grow.

In this research, the developing of the strategy of digital marketing uses the SWOT analysis. SWOT Analysis is a tool used for strategic planning and strategic management in organizations. It can be used effectively to build organizational strategy and competitive strategy [9].

SWOT analysis in determining digital marketing or ecommerce has been carried out among others by: Awais and Samin, the study discuss about advanced SWOT analysis of E-commerce which will comprise of strengths, weaknesses, opportunities and threats faced by e-commerce in current scenario [10]. Study about e-commerce strategic business environment in Indonesia [11]. Yun $\mathrm{Li}$ analyse the current status of Mt. Jiuhua E-commerce tourism in the big data age by using SWOT method in order to find a new solution to develop tourist economy [12]. Hosseini identified strategies based on the analysis of SWOT have a vital role in enhancing the export of agricultural commodities [13].

\section{METHOD}

\section{A. Research Method}

This research uses descriptive method that begins with qualitative approach on secondary data from the Central Bureau of Statistics (BPS) and various research results on agricultural digital marketing. These data are the elements of Strengths, Weaknesses, Opportunities, and Threats of Indonesian agricultural product and its digital marketing. These qualitative data then be set to quantitative value by weight, rank, and total score that is stated in IFAS and EFAS. Digital marketing strategy of Indonesian agricultural product is being developed based on the result of IFAS and EFAS analysis.

\section{B. Data and the Result of Previous Research}

The secondary data collected is a description of Strengths, Weaknesses, Opportunities, and Threats of digital marketing of Indonesian agricultural products. The Secondary data that support this study among others things the percentage of the population who work according to the type of main occupation and generation, 2017 as shown in Table I. The percentage of millennial workers in the agricultural sector is much lower compared to generation $\mathrm{X}$ and baby boomers + veterans

Millennial have a definite preference for certain forms of online advertising. There are digital marketing strategies that are considerably more effective in grabbing the attention of Millennial, motivating repeat visits to a web site, and encouraging Millennial to write online reviews [14].

TABle I. Percentage of Working Population 2017 [15

\begin{tabular}{|l|l|l|l|}
\hline \multicolumn{1}{|c|}{ Description } & \multicolumn{1}{|c|}{$\begin{array}{c}\text { Generation } \\
\text { Y } \\
\text { (Millennial) }\end{array}$} & $\begin{array}{c}\text { Generation } \\
\text { X }\end{array}$ & $\begin{array}{c}\text { Baby } \\
\text { boom + } \\
\text { Veterans }\end{array}$ \\
\hline $\begin{array}{l}\text { Service Workforce and } \\
\text { Sales Force }\end{array}$ & 24.61 & 23.54 & 21.19 \\
\hline $\begin{array}{l}\text { Agriculture, Forestry } \\
\text { and Fisheries Skilled } \\
\text { Workers }\end{array}$ & 16.04 & 23.61 & 43.57 \\
\hline Blue-collar workers & 19.68 & 18.45 & 16.26 \\
\hline
\end{tabular}

Computer, internet and cellular telephone users in Indonesia continue to increase in the 2014-2017 period as shown in Table II. This is a condition that greatly supports digital marketing. The powerful smartphone and other mobile devices have given birth to lots of social media applications and many more in the pipeline. It's importance of mobile social media applications in the current digital marketing arena. The develops valuable insights on mobile social media, which is of great value for mobile marketing and social media marketing managers in the near future [10].

TABLE II. PERCENTAGE OF COMPUTER, INTERNET AND CELLPHONE USER [2]

\begin{tabular}{|l|l|l|l|}
\hline Year & Computer users & Internet users & Cell phone users \\
\hline 2014 & 17.30 & 17.14 & 51.49 \\
\hline 2015 & 18.71 & 21.98 & 56.92 \\
\hline 2016 & 19.14 & 25.37 & 58.30 \\
\hline 2017 & 19.11 & 32.34 & 59.59 \\
\hline
\end{tabular}


The unfavourable condition is that the average wage of grey collar and blue collar workers in the agricultural sector is lower than the manufacturing and service sectors as shown in Table III. This will reduce millennial appeal to work in the agricultural sector so that it can hamper digital marketing of agricultural product.

TABLE III. AVERAGE OF NET INCOME PER MONTH BY MAIN INDUSTRY (THOUSAND RUPIAHS) 2019 [16]

\begin{tabular}{|l|c|c|c|c|}
\hline \multirow{2}{*}{ Main Industry } & \multicolumn{4}{|c|}{ Main Occupation } \\
\cline { 2 - 5 } & $\begin{array}{c}\text { White- } \\
\text { collar }\end{array}$ & $\begin{array}{c}\text { Grey- } \\
\text { collar }\end{array}$ & $\begin{array}{c}\text { Blue- } \\
\text { Collar }\end{array}$ & Average \\
\hline Agriculture & - & $1,188.40$ & $1,068.30$ & $1,128.35$ \\
\hline Manufacture & $2,123.10$ & $1,454.20$ & $1,794.80$ & $1,790.70$ \\
\hline Services & $1,508.70$ & $1,084.10$ & $1,364.70$ & $1,319,17$ \\
\hline
\end{tabular}

Indonesia's digital marketing infrastructure is also marked by Index of Indonesian technology and information development (IP-TIK). In 2016 is 4.34 which is a bigger number than the 2015 (IP-TIK) of 3.88. at 2017, the (IP-TIK) grows to 4.99. the (IP-TIK) at province level is growing from 2016 to 2017. The province with the highest (IP-TIK) at 2017 is DKI Jakarta, with the index of 7.61while the province with the lowest (IP-TIK) is Papua with index of 2.95 [17].

Other secondary data is Creative economic activities that can encourage digital marketing of agricultural products, among other things is the high percentage of culinary business activities that require raw materials of food agricultural products. This will be a great digital marketing opportunity. Number of creative economy companies in 2016 are interior design $798(0,01)$, craft $1,194,509 \quad(14,56 \%)$, culinary $5,550,960$ (67,66\%), fashion 1,230,988 (15,01\%). Total Creative Economy Companies 8,203,826 [18].

The results of previous studies on digital marketing of agricultural products in Indonesia among other things is study on Limakilo. Limakilo is one of the e-commerce companies in Indonesia which offers shallot as main commodity. The Company markets its products by being a direct mediator between farmers and consumers [6]. The most used social media types are Facebook, WhatsApp, Instagram, and blackberry message. The biggest advantage of real time communication with the customers is more intensive, effective, and efficient supplier [19]. Another study shows the use of the internet in marketing has not run optimally [20].

Only few who actively use social media as their promotion tools and they have not separated their online shop account with their personal account, several others use it occasionally, and the rest participants have never used social media marketing for being lack of technological skill. All participants show great interest to use social media marketing continuously [21].

\section{RESULTS AND DISCUSSION}

The strength of Indonesian agricultural products lies in the aspect of the number and variety of food crops, plantations, livestock, fisheries and forestry for domestic and export needs. The results of the export competitiveness study show that many Indonesian products are included in the rising star category in the ASEAN market [1]. This shows that the market is still potential for Indonesia.

Weaknesses in the development of digital marketing of agricultural products as internal factors, especially weak resources such as the low role of millennial farmers while older farmers are more dominant [17], this is related to the low wages of agricultural workers [18]. The bulky and perishable nature of agricultural products requires good logistical handling [22].

The weight, rate, and total score of each internal factor element and Indonesian agricultural product digital marketing weaknesses are being showed in IFAS at Table IV. The analysis result shows that the difference between the total score of strengths and weaknesses is -0.18 .

TABLE IV. INTERNAL FACTOR ANALYSIS SUMMARY (IFAS)

\begin{tabular}{|l|l|l|l|}
\hline \multicolumn{1}{|c|}{ Descriptions } & Weight & Rating & $\begin{array}{c}\text { Total } \\
\text { score }\end{array}$ \\
\hline \multicolumn{1}{|c|}{ Strengths } & & & \\
\hline Product growth & 0.09 & 4 & 0.36 \\
\hline Product variety & 0.10 & 4 & 0.40 \\
\hline Product exports & 0.10 & 3 & 0.30 \\
\hline Product affordable price & 0.08 & 3 & 0.24 \\
\hline Agro-industrial raw material & 0.10 & 2 & 0.20 \\
\hline \multicolumn{1}{|c|}{ Weaknesses } & $\mathbf{0 . 4 7}$ & & $\mathbf{1 . 5 0}$ \\
\hline \multicolumn{1}{|c|}{ mumber of millennial } & 0.08 & 3 & 0.24 \\
\hline Long marketing chain & & 2 & 0.18 \\
\hline $\begin{array}{l}\text { Small as } \\
\text { farmer }\end{array}$ & 0.10 & 3 & 0.30 \\
\hline $\begin{array}{l}\text { Baby boomers and veterans ajority farmers } \\
\text { majorat }\end{array}$ & 0.08 & 3 & 0.24 \\
\hline Low e-commerce penetration & 0.07 & 4 & 0.28 \\
\hline Bulky and perishable products & 0.06 & 4 & 0.24 \\
\hline Not yet good of logistics services & 0.05 & 4 & 0.20 \\
\hline Low farmers wages & $\mathbf{0 . 5 3}$ & & $\mathbf{1 . 6 8}$ \\
\hline Total Grand Total & $\mathbf{1 . 0 0}$ & & $\mathbf{3 . 1 8}$ \\
\hline & & & \\
\hline
\end{tabular}

Opportunities for the development of digital marketing of agricultural products are quite large as shown in Table V. The opportunities are based on secondary data that can be collected. Improving the existing communication infrastructure in the Ecommerce road map will encourage consumers to have a close relationship with marketers.

The number of great millennial as a demographic bonus is a very important opportunity for the development of digital marketing of agricultural products. This is seen from the results of research on positive millennial attitudes towards online advertising [23]. This is supported by other research that some of opportunities of digital marketing are: easy consumer reach and direct advertising [10].

Another important opportunity there are many of cell phone users and sufficient number of internet users that describe Easy Consumer Reach [2]; Large number of culinary business [18]; High e-commerce transaction High e-commerce transactions that can be seen from the increase in the value of Indonesia's ecommerce retail business from 1.94 billion USD in 2014 to 3.22 billion USD in 2015 [24], and increasing the need of agroindustry raw materials, which can be seen from the high 
production increase of the food and beverage industry by $12.7 \%$ (уоу) [25].

Weight, rate, and total score of each external factor element is being showed in EFAS at Table V. The result of the analysis shows that the difference between the total score of Opportunities and Threats is 1.06 .

TABLE V. EXTERNAL FACTOR ANALYSIS SUMMARY (EFAS)

\begin{tabular}{|l|l|l|l|}
\hline \multicolumn{1}{|c|}{ Descriptions } & Weight & Rating & $\begin{array}{c}\text { Total } \\
\text { score }\end{array}$ \\
\hline \multicolumn{1}{|c|}{ Opportunities } & & & \\
\hline E-commerce road map & 0.10 & 4 & 0.40 \\
\hline Millennial demography bonus & 0.07 & 3 & 0.21 \\
\hline Many of cellphone users & 0.09 & 4 & 0.36 \\
\hline $\begin{array}{l}\text { Sufficient number of internet } \\
\text { users }\end{array}$ & 0.04 & 3 & 0.12 \\
\hline Growth of income per capita & 0.05 & 3 & 0.15 \\
\hline Many of culinary business & 0.10 & 3 & 0.30 \\
\hline High e-commerce transaction & 0.05 & 2 & 0.10 \\
\hline $\begin{array}{l}\text { The increase in demand for agro- } \\
\text { industrial raw materials }\end{array}$ & 0.10 & 4 & 0.40 \\
\hline Total agricultural product & 0.10 & 3 & $\mathbf{2 . 0 4}$ \\
\hline $\begin{array}{l}\text { Low average development index } \\
\text { of information and technology }\end{array}$ & 0.06 & 2 & 0.12 \\
\hline $\begin{array}{l}\text { Little and agricultural } \\
\text { Startups }\end{array}$ & 0.08 & 3 & 0.30 \\
\hline $\begin{array}{l}\text { Small valuation of } \\
\text { product startups }\end{array}$ & 0.04 & 2 & 0.24 \\
\hline $\begin{array}{l}\text { Needs of foreign funding for e- } \\
\text { commerce and } \\
\text { development }\end{array}$ & 0.03 & 2 & 0.08 \\
\hline Very little unicorn startups & $\mathbf{0 . 4 0}$ & & $\mathbf{0 . 9 8}$ \\
\hline Weak internet infrastructure & 0.04 & 2 & $\mathbf{3 . 0 2}$ \\
\hline $\begin{array}{l}\text { Increasing report number of e- } \\
\text { commerce issues }\end{array}$ & 0.03 & \\
\hline Total & & & 0.10 \\
\hline Grand Total & 0.06 & \\
\hline
\end{tabular}

Some of challenges of digital marketing are: Limitation of Internet Access. The obstacles faced in developing start-ups in Indonesia are funding, net-working, team solidity, trial and error, lack of experience, not being accepted by the market, and regulations are not ready. Likewise, the increasing number of e-commerce problem reports [25]. This shows that there are still few active start-ups, low funding, foreign funding needs, and weak internet infrastructure.

The strategy that can be developed based on the combination of each SWOT element is showed SWOT Matrix. It shows that the strategy is a combination of strengths and opportunities (SO strategy), Weaknesses and Opportunities (WO strategy), Strengths and Threats (ST strategy) and Weaknesses and Threats (WT strategy). The strategies which are developed is focused on Indonesian agricultural product digital marketing in order to cut the market chain through the role of start-ups so that the agricultural product distribution can run efficiently and the farmer income would rise through the increase of farmers share percentage.

Figure 1 show the strategic position digital marketing of Indonesian agricultural product. According to the difference of the total score between strengths and weaknesses $-0,18$ and between opportunities and threats 1,06, the Indonesian agricultural product digital marketing is on the conservative strategy, which is Weaknesses-Opportunities (WO) combination strategy. The WO strategy purposes to fix the internal weaknesses of agricultural product digital marketing through taking advantages of the external opportunities that can increase the performance of Indonesian agricultural product digital marketing.

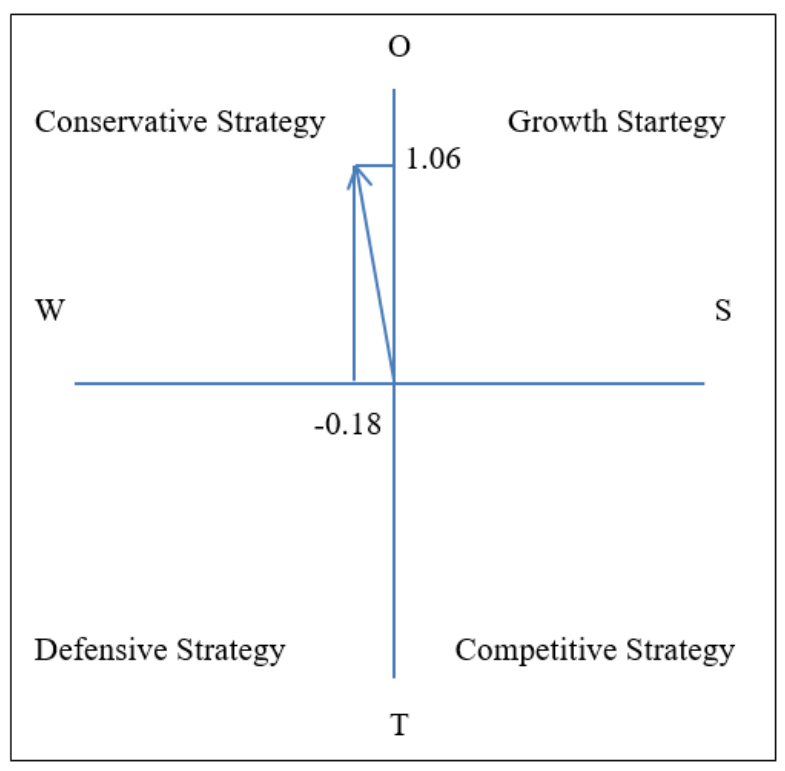

Fig. 1. Position digital marketing of Indonesian agricultural product.

WO strategy in developing digital marketing of Indonesian agricultural products requires hard work in an effort to correct various weaknesses as shown in Table IV. Then take advantage of a very wide range of opportunities as shown in Table V. The priority scale in this improvement is directed at accelerating the increase in digital marketing activities of Indonesian agricultural products. Conversely, the various opportunities that exist must be utilized as much as possible so that it can become a momentum to increase the performance of digital marketing of Indonesian agricultural products in the future.

The combination WO strategies are: 1) Shortening the chain of agricultural product marketing through digital marketing supported by start-ups; 2) Intensifying the number of agricultural product start up through trainings and funding based on the e-commerce road map; 3) Pushing the millennial farmers to manage agribusiness to make use the increasing people's income; 4) Providing seminars to the farming groups about the advantages and profit of digital marketing; 5) Giving the appropriate digital marketing training to the millennials based on the e-commerce road map; 6) Providing cheap and affordable cell phone devices that can be bought in instalments without interest fee; 7) Giving the subsidies and creative farming training to grow the number of millennial farmers to utilize demography bonus; 8) Increasing the e-commerce penetration of agricultural product by taking benefits of cell phone and internet users; 9) Growing millennial farmer income through commercial agricultural product; 10) Escalating farmer income through partnerships with culinary and agroindustry business in the agricultural product digital 
marketing; and 11) Providing great logistic service for agricultural products in order to fulfil the culinary and agroindustry business.

\section{CONCLUSION}

The results of the SWOT analysis show a) Strengths: product growth, product variety, product exports, product affordable price and agro-industrial raw material; b) Weaknesses: long marketing chain, small number of millennial farmers, baby boomers and veterans as majority farmers, low e-commerce penetration, bulky and perishable products, not yet good of logistics services and low farmers wages; c) Opportunities: e-commerce road map, millennial demography bonus, many of cell phone users, sufficient number of internet users, growth of income per capita, many of culinary business, high e-commerce transaction and the increase in demand for raw materials of agro-industrial; d) Threats: low average development index of information and technology, little of agricultural product start-ups, small valuation of agricultural product start-ups, needs of foreign funding for e-commerce and start up development, very little unicorn start-ups, weak internet infrastructure and increasing report number of ecommerce issues.

The strategies in developing digital marketing of Indonesian agricultural products that can be developed are combination of Weaknesses-Opportunities (WO) strategy consists of: 1) Shortening the chain of agricultural product marketing through digital marketing supported by start-ups; 2) Intensifying the number of agricultural product start up through trainings and funding based on the e-commerce road map; 3 ) Pushing the millennial farmers to manage agribusiness to make use the increasing people's income; 4) Providing seminars to the farming groups about the advantages and profit of digital marketing; 5) Giving the appropriate digital marketing training to the millennials based on the e-commerce road map; 6) Providing cheap and affordable cell phone devices that can be bought in instalments without interest fee; 7) Giving the subsidies and creative farming training to grow the number of millennial farmers to utilize demography bonus; 8) Increasing the e-commerce penetration of agricultural product by taking benefits of cell phone and internet users; 9) Growing millennial farmer income through commercial agricultural product; 10) Escalating farmer income through partnerships with culinary and agroindustry business in the agricultural product digital marketing; and 11) Providing great logistic service for agricultural products in order to fulfil the culinary and agroindustry business.

Based on these strategies, agricultural products will be marketed more efficiently and effectively thereby, it will increase farmer share through various supports: the increase number of agricultural start-ups, millennial management of onfarm and off-farm agribusiness, farming group extension about the benefits of digital marketing, millennial training in digital marketing management, provision of inexpensive mobile phone devices that is accessible by millennials, subsidies for millennia ls who develop creative agribusiness, penetration increase of e-commerce in agricultural products, provision of good agricultural product logistics, increase in millennial farmers income through product development of commercial agriculture and partnership with culinary and agro-industrial companies

\section{REFERENCES}

[1] E.A. Ningsih and W. Kurniawan, "Daya Saing Dinamis Produk Pertanian Indonesia di Asean,” Jurnal Ekonomi Kuantitatif Terapan, vol. 9, no. 2, pp. 117-125, 2016.

[2] BPS, Statistik Telekomunikasi Indonesia (Telecommunication Statistics in Indonesia ), 2017

[3] J.J.L.Garcia, D. Lizcano, C.M.Q. Ramos, and N. Matos, "Digital Marketing Actions That Achieve a Better Attraction and Loyalty of Users: An Analytical Study," Future Internet, vol. 11, no. 130, pp. 1-16, 2019.

[4] A. Yurkovskaya, I. Prishchepa, S. Losmakov, and U. Parkhimenka "Reflections on Marketing Strategy and Digital Marketing Infrastructure along the Belt and Road Project," Central European Researchers Journal, vol. 4 , no. 1 , pp. 8-16, 2018

[5] Z. Andreopoulou, G. Tsekouropoulos, T. Koutroumanidis, M. Vlachopoulou, and B. Manos, "Typology for E-business Activities in the Agricultural Sector," International Journal of Business Information Systems, vol. 3, no. 3, pp. 231-251, 2008.

[6] A. Yashinta, "Model bisnis E-commerce Produk Pertanian (Studi kasus pada PT. Limakilo Maju Bersama petani)," Jurnal Manajemen dan Bisnis (Performa)". Vol X1V. No 2. 2017, pp. 138-151

[7] S. Sabha, "SWOT Analysis of Business or Electronic Commerce (ECommerce). International Journal of Education and Research," vol. 5, no. 5, pp. 105-112, 2017.

[8] V. Bojkić, M. Vrbančić, D. College, and M. Čut, "Digital Marketing in Agricultural Sector," Entrenova, pp 136-140, 2016

[9] E. Gurel and T.A.T. Merba, "SWOT Analisys: A Theoritical Review," The Journal of International Social Research, vol. 10, no. 51, pp. 994 1006, 2017

[10] M. Awais and T. Samin, “Advanced SWOT Analysis of E-Commerce," IJCSI International Journal of Computer Science Issues, vol. 9, no. 2, pp. 569-574, 2012.

[11] D. Aribawa, "E-commerce Strategic Business Environment Analysis in Indonesia," International Journal of Economics and Financial Issues, vol. 6, no. S6, pp. 130-134, 2016.

[12] Yun Li, "SWOT Analysis on the E-commerce System of Mt.Jiuhua Tourism in the Big Data Age," Accounting and Finance Research, vol. 5, no. 2, pp. 84-88, 2016.

[13] F. Hosseini, H. Sadighi, S.A. Mortazavi, and H. Farhadian, "An ECommerce SWOT Analysis for Export of Agricultural Commodities in Iran,”J. Agr. Sci. Tech. vol. 21, pp. 1641-1656, 2019.

[14] K. Taken Smith, "Longitudinal study of digital marketing strategies targeting Millennials," Journal of Consumer Marketing, vol. 29, no. 2, pp. 86-92, 2012

[15] Kementerian Pemberdayaan Perempuan dan Perlindungan Anak, Statistik Gender Tematik: Profil Generasi Milenial Indonesia. Jakarta, 2018.

[16] BPS-Statistics Indonesia, Income Statistics February 2019, 2019

[17] BPS, Indeks Pembangunan Teknologi Informasi Dan Komunikasi (IP TIK) Indonesia Tahun 2017 Sebesar 4,99 Pada Skala 0-10, 2017.

[18] BPS, Business Profile/Company 16 Ekraf Subsectors Based on Economic Census 2016, 2016.

[19] T. Pradiani, "Pengaruh Sistem Pemasaran Digital Marketing Terhadap Peningkatan Volume Penjualan Hasil Industri Rumahan,” Jibeka, vol. 11, no. 2, pp. 46-53, 2017

[20] A. Asriani, "The Use of Internet As Marketing Media of Agriculture Prominent of Gorontalo Province," Jurnal Komunikasi KAREBA, vol. 1, no. 3, pp. 249-257, 2018.

[21] D. Purwana, R. Rahmi, and S. Aditya, "Pemanfaatan Digital Marketing Bagi Usaha Mikro, Kecil, Dan Menengah (UMKM) Di Kelurahan Malaka Sari, Duren Sawit," Jurnal Pemberdayaan Masyarakat Madani, vol. 1 , no. 1 , pp. $1-17,2017$ 
[22] W.P. Rahayu and W. Adhi, "Good Logistic Practices as the Main Supported for Tropical Fruit Export," Jurnal Manajemen Transportasi \& Logistik (JMTransLog), vol. 02, no. 01, pp. 93-105, 2015.

[23] E.P. Marcelin, M. Marry, M.F. Anggasta, Al-Barru, and P. Ngadianto, Sikap Pelanggan Millennial Indonesia Terhadap Iklan Online. Program MM Sekolah Bisnis dan Ekonomi Universitas Prasetiya Mulya, 2015.
[24] Kementerian Kominfo, Study Ekonomi Digital di Indonesia Sebagai Pendorong Utama Pembentukan Industri Digital Masa Depan, 2018.

[25] Kementeriaan Perindustriaan, Analisis Perkembangan Industri. Edisi II2018,2018 